\title{
Special Announcement
}

\section{FIRST ANNOUNCEMENT AND CALL FOR PAPERS}

\author{
SIXTH INTERNATIONAL \\ CONGRESS OF THE WORLD \\ ORGANISATION OF GENERAL \\ SYSTEMS AND CYBERNETICS \\ ORGANISED BY THE COLLÈGE DE \\ SYSTÉMIQUE OF AFCET \\ (ASSOCIATION FRANÇAISE POUR \\ LA CYBÉRNETIQUE, ECONOMIQUE \\ ET TECHNIQUE)
}

September 10-14, 1984, Paris (France)

This triennial congress is sponsored by many international and national bodies. The Congress Committee consists of the following members: Elie Bernard-Weil (CNEMATER, Hôpital de la Pitié, Paris; Pierre Davous (Euroquip, Vaucresson); Alain Dussauchoy (Université Lyon I, Lyon); Jean-Louis Le Moigre (GRASCE, Université d'Aix-Marseille, Aix-en-Provence); Bernard Paulré (Université Paris IX, Paris); Robert Vallée (Université Paris-Nord, Paris); Bernard Walliser (Ecole Nationale des Ponts et Chaussées, Paris). There are also two co-opted members representing the WOGSC, viz. T. C. Helvey (Director for External Affairs of the WOGSC; Norbert Wiener Gold Medallist, USA) and J. Rose (Director-General of the WOGSC, UK).

\section{Aims and Themes}

The aim of this interdisciplinary congress, which follows the previous five congresses (London, 1969; Oxford, 1972; Bucharest, 1975; Amsterdam, 1978; Mexico City, 1981) is to present contemporary aspects of Cybernetics and Systems and to examine various developments in these and allied fields.

The following are the proposed themes and topics for the congress: Foundations, Epistemology, Analogy,
Modelisation, General Methods of Systems, History of Cybernetics and Systems Science Ideas; Information, Organisation, Morphogenesis, Self-reference, Autonomy; Dynamic Systems, Complex Systems, Fuzzy Sets; Physico-Chemical Systems; Engineering Systems, Automation, Simulation, Robotics, Artificial Intelligence, Learning; Biological Systems, Neurocybernetics, Autogenesis, Physiology, Systemic Therapy, Ethology, Ecology; Human and Social Systems, Anthropology, Economics, Development, Management, Education.

It is to be noted that no topic relevant to cybernetics and systems in the widest sense or type of approach is excluded. Papers will be accepted on the basis of submitted abstracts (two copies), containing between 500 and 1,000 words, in French or English. Each abstract should show the following details: Title of paper (full and abridged), name(s) of author(s) and relevant address(es). The abstracts (in due course, the final papers) should be sent to:

\section{Sixth International (WOGSC) Congress}

Comité de Lecture

\section{AFCET}

156 boulevard Péreire, F.75017 Paris, France

(Tel. 1-766-24-19; telex 290163 Eurtel Code 235)

\section{DEADLINE FOR THE RECEPIT OF ABSTRACTS-OCTOBER 15, 1983. \\ DEADLINE FOR THE RECEIPT OF \\ FINAL PAPERS-MARCH 15, 1984.}

Authors will be notified in January, 1984, about the acceptance of their papers.

\section{Addenda}

1. The official languages of the Congress are French and English. Simultaneous translation facilities will be available (from French into English, and vice versa) during the plenary sessions.

2. The Sixth Congress is held a week before the SICOB CONVENTION in Paris.

3. Please direct all enquiries to AFCET, as above. 